\title{
The Category of Victim "From Below": the Case of the Movement of Victims of State Crimes (MOVICE) in Colombia
}

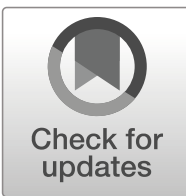

\section{Nadia Tapia Navarro ${ }^{1}$}

Published online: 2 July 2019

(C) Springer Nature B.V. 2019

\begin{abstract}
In this article, I focus on the work of the Movement of Victims of State Crimes (Movice) in Colombia. The work of Movice, I suggest, is an example of how the category of "victim" from international law discourse is adopted and used from below by victims of mass atrocities. I show that, through this category, Movice attempts to introduce an alternative narrative of the internal armed conflict in which the state is a perpetrator of violence against civilian population as part of a practice of elimination of political opposition through violent means. To do this, I focus on three political opportunities in which Movice deployed the category of victim between 2005 and 2016. I suggest that Movice is an example of how a movement of victims can adopt categories of international law to frame their struggles and, in doing so, infuse them with new contents.
\end{abstract}

Keywords Victims of mass atrocities · Transitional justice $\cdot$ Colombia $\cdot$ Social movements . Victims

\section{Introduction}

Colombia's internal armed conflict lasted for over five decades. In this time, the conflict produced a shocking number of victims of different forms of mass atrocities, including massacres, extrajudicial executions, forced disappearances, torture and forced displacement. The complexity of the conflict should not be underestimated. ${ }^{1}$ To begin with, it is a long conflict, lasting for more than half a century and existing in parallel with

\footnotetext{
${ }^{1}$ Briefly highlighting different factors that make the Colombian conflict particularly complex: Saffon, Uprimny (2007).
}

Nadia Tapia Navarro

nadia.tapia@helsinki.fi

1 Erik Castrén Institute, Faculty of Law, University of Helsinki, Helsinki, Finland 
democratic processes and regularly held elections. During this time, different kinds of armed groups, namely insurgent guerrillas, the state army and paramilitary groups, battled each other. ${ }^{2}$ Moreover, the intensity and forms of violence changed and degraded over time, its geographical distribution was unequal affecting mostly poor rural communities, and the different armed groups and their alliances evolved, expanded and shifted. In addition, the drug-trafficking business allowed illegal armed actors to increase their economic and military power. Although in 2016, a peace agreement was signed between the Colombian government and the biggest and oldest guerrilla FARC$\mathrm{EP}$, today there are several reports of ongoing violence in the country (e.g. Reuters, 2019; NRC, 2019).

Although all the armed groups - including the army - attacked civilian population as a part of their war strategies (GMH, 2013, 35), paramilitary groups are considered one of the most violent actors in the conflict and the primary force responsible for millions of internally displaced persons in Colombia (García-Godos and Lid, 2010,491). Moreover, today, several sources affirm that the actions of paramilitary groups were at times supported, and at other times tolerated, by the army who saw them as an ally that could do the 'dirty work' it was not allowed to do (Guzmán, Sánchez, Uprimny, 2010, 99-100; GMH, 2013, 140). ${ }^{3}$ Unlike the guerrillas, the paramilitary groups are pro-systemic actors that never intended to overthrow the government or to defeat the Colombian army, but rather to support their struggle against guerrilla groups through illegal means (Saffon, Uprimny, 2007, 5). With time, the paramilitary evolved to become armed mafias with important allies (such as entrepreneurs and politicians), singularly organising different legal and illegal businesses (drug trafficking, security services, land grabbing and corruption) (GMH, 2013, 27 et seq). In 1997, a nationwide coalition of paramilitary groups was formed: The United Self-Defences of Colombia (AUC).

During the conflict, civilian population has suffered from violence disproportionally as, for each combatant killed, four civilians have died (GMH, 2013, 32). In a country of 49 million people, by the end of 2018 , more than 8 million individuals had officially registered as victims of the conflict. ${ }^{4}$ These victims have become an important constituency, not only because of their high amount, but also due to their active participation in political discussions regarding the conflict. Today, some consider that the victims have emerged as an important political actor in Colombia (Rettberg, 2013; Vera Lugo, 2016). The language of international law and the category of victim of mass atrocities have been important assets for this emerging political actor.

In this article, I focus on the work of a nationwide umbrella organisation of victims of mass atrocities, namely, the Movement of Victims of State Crimes (Movice, for its initials in Spanish). The work of Movice, I suggest, is an example of how the category

\footnotetext{
${ }^{2}$ The complexity of the conflict has prompted scholars to assert that it is difficult to classify this conflict. See for instance: IEPRI (2006) and Saffon, Uprimny (2007).

${ }^{3}$ Moreover, in different moments of the conflict, the government issued legal frameworks that enabled the creation of the paramilitary forces (Guzmán, Sánchez, Uprimny, 2010, 97). Though paramilitary groups may have begun as self-defence groups, their constitution and purpose changed in time. With time, they have evolved to almost become armed mafias, with important allies (such as entrepreneurs and politicians), singularly organizing different legal and illegal businesses (drug trafficking, security services, land grabbing and corruption) (GMH, 2013, 27 et seq).

${ }^{4}$ See the Unique Registry for Victims (Registro Único de Víctimas) https://www.unidadvictimas.gov. co/es/registro-unico-de-victimas-ruv/37394
} 
of the victim from international law discourse is adopted and used from below by victims of mass atrocities. Building their identity around the category of victim and resorting to victims' rights are powerful tools for these local actors, not only because this allows them to frame these injustices as global issues (García-Godos, 2013, 245; Tarrow, 2011, 252), but also because the indeterminacy of human rights (Petman, 2012) allows them to infuse them with different meanings. In other words, Movice does not simply resort to the vocabulary of human rights as one with a fixed content; instead, it shapes its meaning.

There is a vast amount of literature coming from different areas of expertise about victims of mass atrocity in the context of Colombia's long internal armed conflict (e.g. García Arboleda, 2013; Sandoval Rojas, 2015; Pardo Abril, Ruiz Celis, 2016). In this literature, there is a growing number of works critically reflecting on how the category of victim itself relates with political emancipation either by allowing or impeding it. Some of the works focus - partly or entirely — on the work of Movice (e.g. Diaz, 2008; Gómez Correal, 2015). For instance, Gómez Correal (2015) investigates how intimate ties of caring and belonging are politicised in the context of Colombian violence and how this led to the creation of Movice. Moreover, some authors see-implicitly or explicitly-the emancipatory potential of the category of victim (Gómez Sánchez, 2014, 195; Jimeno et al., 2015), while others highlight its limitations (Fuentes-Becerra, 2016; Acebedo Pérez, 2016; Pedraza and Álvarez, 2016). When thinking about the effects of victimhood, the idea of it allowing or limiting political subjectivity has been brought up (Delgado Barón, 2011).

This article seeks to contribute to these questions by focusing on the work of Movice during its first 11 years (2005-2016), ${ }^{5}$ evaluating the ways in which it uses the category of victim in light of different opportunities and reflecting on its results. I will highlight two different aspects. First, Movice does not simply adopt the category without contention, but it infuses it with particular meanings. In adopting the language of international law, Movice is not only advocating for the rights of victims as developed by international law, but it is also contesting the official narrative of the conflict and suggesting an alternative reading of Colombian violence. In this reading, the Colombian state, through its army and paramilitary actions, was not only fighting guerrilla violence, but also persecuting political opposition. Thus, to Movice, Colombian violence cannot be entirely explained by the existence of an internal armed conflict. Instead, some of this violence is explained by the existence of a sustained practice of political persecution, which makes it closer to the violence experienced by other LatinAmerican countries. Thus, in a context where the logics of the conflict are highly contested, the category of victim allows to legitimately challenge the prevailing narratives of the conflict. This is possible because the category of victim allows to focus on factors around the violation suffered, such as who the perpetrators are and which methods were used. Moreover, identifying themselves as victims and grounding their claims in the language of transitional justice gives them enhanced legitimacy that allows them to position themselves in the political landscape.

Second, in using the category of victim to frame their demands of justice, victims become a political subject that not only challenges the specific legal content of such category, but also challenges the stereotype according to which victims are necessarily

\footnotetext{
${ }^{5}$ The period is delimited by Movice's creation in 2005 and the signature of the peace agreement in 2016.
} 
passive, defenceless and docile (similarly, from an anthropological perspective: Gómez Correal, 2015 and Gómez Correal, 2016, 113-4). Through their actions, they embody a victim that does not comply with such stereotype, and thus are able to influence its content, to change it and to redraw its contours (Quintana, 2016, 108-11). This way, the work of Movice, and other similar initiatives, has allowed for a cultural shift in which victims of mass atrocities can also be seen in Colombia as powerful political actors. Over the years - and together with different other initiatives - the actions of Movice managed to put victims at the centre of political discussions regarding the internal conflict, becoming an important actor and reference in these discussions.

The article is informed by three different types of sources as well as by my observations during a 4-month visit to the Universidad de los Andes, Bogotá. ${ }^{6}$ First, I used a body of primary and secondary sources related to Movice's work and more broadly to the recent Colombian political context. Among secondary sources, academic works from different fields (mainly, law, sociology and anthropology) were considered, as well as works produced by NGOs. Some of Movice's members are also academics; this is the case of Gómez Correal whose works were used in particular to understand the climate of contestation over the definition of the victim in the context of the discussions leading to the Final Agreement between the Colombian government and the FARC-EP. Movice itself has authored some publications and features different resources in its website, including various communiqués. Second, a body of news clips from different media mentioning the word 'Movice' from 2008 onwards (the first year that materials were made available on the Internet). These clips were retrieved from newspapers and magazines with national (El Espectador and Semana) and regional (El Colombiano, El Heraldo) coverage, as well as virtual media (Silla Vacia, Colombia Plural). Third, an in-depth semi-structured interview conducted with six Movice members. News clips and secondary sources were used to ascertain the context in which Movice moved and how they participated in the political debate around victims' rights, as well as the impact of this participation. Movice's communiqués, as well as the interviews with Movice members, were especially relevant to ascertain their own articulation of the language of transitional justice and the category of victim. ${ }^{7}$

The approach in this article assumes an understanding of the category of victim, and more generally of law as a discourse. ${ }^{8}$ This means that the legal category of the victim is not viewed as a fixed category with a specific meaning that can be detached from its

\footnotetext{
6 (Anonymised)

7 The interview contained nine questions regarding their identity as victims, the differences of Movice vis-àvis other victims' organizations in Colombia, Movice's main achievements, current political contexts and challenges of Movice's work, and the impact of the peace agreement for Movice's work. All interviews were conducted in Bogotá. Three of the interviewees held a special position in the organization; two of them were spokesmen, and one was the contact person for Bogotá chapter. The other three participated actively in Movice's activities in Bogotá's chapter. All of them were recorded with prior consent of the interviewees, who also all consented in giving their names for this article.

${ }^{8}$ As pointed out by one of the anonymous reviewers, Movice's activism is not only discursive but also embodied. In this sense, another way in which this study could have been done is by an ethnographic study of the work of Movice. Such a study, however, goes well beyond the scope of the research done for the purposes for this article. However, the work of Diana Gómez Correal (2015), who is both an activist in Movice and an academic in the field of anthropology, can be consulted as it produces an ethnographic account of the organization. In her own words, her doctoral dissertation is 'the product of militant, participatory, and cointentional research that has been designed as a decolonial effort to decolonize the production of knowledge in a concrete moment: the transition to peace in Colombia.' (Gómez Correal, 2015)
} 
context. Instead, its meaning is embedded in the interactions between social groups and complex societal structures (Ian Parker cited in Phillips, Hardy, 2002, 3-4). Moreover, the reader should be aware that, in studying the case of Movice, in this article, I offer a representation of their work that is based on the materials described earlier. The reader is advised not to understand this act of representation as an act of 'discovery' of the other (Alcoff, 1991-1992); instead, I am actively producing that representation. I believe that this representation is justified by the need to see past the - often highlighted-vulnerability of the victims and, instead, showing that their actions can be highly agentic, specifically with regard to the way they wield this legal category. ${ }^{9}$ In the following section, as well as in the conclusion, I develop these ideas further.

The structure of this paper is as follows: First, I connect the discussions over the category of victim in international law and transitional justice with the notion of international law from below and some concepts borrowed from the sociology of social movements' literature. All these provide an essential theoretical framework that allows the reader to understand the approach of this article that focuses on the work of an organisation such as Movice ("The Victim of International Law: From Above and 'From Below' section). In "Movice and the Category of Victim 'From Below"' section, I continue by explaining the creation and main characteristics of Movice and then go on to analyse its work as an organisation where the concept of victim is central. I focus on three different moments that can be understood as political opportunities (Tarrow, 2011, 160 ) in which Movice highlights the specificities of their victimhood in relation to their perpetrators and, as a consequence, suggests an alternative narrative of the conflict: first, its creation in 2005; second, the rally of March 6, first organised in 2008; and third, the peace negotiations between the Farc and the Colombian government, leading to the Final Agreement signed in 2016. In these three moments, Movice deploys the category of victim in different ways, with different difficulties and degrees of success. I conclude by reflecting on how the way in which the victims produce meaning through the category of victim (as well as its related legal framework) can be understood as emancipatory.

\section{The Victim in International Law: From Above and From Below}

In this section, I seek to trace a line connecting the idea that the category of "victim" is central to international law and transitional justice discourses, on the one hand, and the importance of understanding the uses that victims themselves make of this category at the domestic level, on the other. This line is built with three different bodies of work: first, critical approaches to international law and the category of victim in particular; second, different approaches that study the workings of non-institutional actors who use the language of international law, which have used the label from below; and third, some of the categories developed by sociologists of social movements. The concepts developed briefly in this section should help the reader to appreciate the theoretical framework that underpins both the focus and the arguments discussed in this article.

\footnotetext{
${ }^{9}$ On the idea of representing others in this way and the possible reasons for its justification see Alcoff (19911992).
} 
In international law, several developments in the aftermath of World War II would aim at giving the individual person a new centrality in an area in which states had long been the traditional actors. Human rights treaties would recognise the individual person as a rights holder and would grant individuals, who suffered harm from a violation to international law, the right to appear before international organisms and to claim for reparation, known as the right to petition (Cançado Trindade, 2011). ${ }^{10}$ In practice, this means that individuals only have procedural capacity before international organisms as victims of human rights violations. It is because of this that the concept of victim is central to human rights to the point that it has been suggested that the metaphor of the victim is the giant engine that drives the human rights movement (Mutua, 2001).

However, different scholars have underscored that the victim is usually portrayed by different human rights operators as passive, docile and innocent (Mutua, 2001; Wilson, 2009). An important effect of representing the victim as essentially powerless is that others are legitimised to act on her behalf. In this sense, Urueña contends that the emancipation promised by human rights law 'is not inspired by a thriving human spirit, but by the empowerment of bureaucracies' (Urueña, 2012, 93). Moreover, this also explains how this portrayal is re-produced by different operators, as their work is legitimised precisely by the idea that it is being done for the victims. Another effect of this representation is that it impedes us from identifying and fostering practices of victims as agentic, and perhaps, emancipatory. ${ }^{11}$ This representation of the victim as essentially disempowered has permeated other areas of law that deal with victims of human rights violations, and more specifically with victims of mass atrocities, such as international criminal law and transitional justice (Clarke, 2009; Kendall, Nouwen, 2014; Fletcher, 2015; Madlingozi, 2010; McEvoy, McConnachie, 2013, SchwöbelPatel, 2016).

Moreover, heavily influenced by the language of human rights and international law, transitional justice has developed rapidly in the recent decades to become today the common language in which political transitions are discussed, whether if it is a transition from dictatorial to democratic regimes or from armed conflicts to peace (Mc Evoy, 2008, 15). In this language, the law - and international law in particularplays a central role, not only at the academic level but also at the level of policy and practice (Mc Evoy, 2008, 16). This centrality not only results in the adoption of the stereotype of the passive victim (as explained above), but also goes hand in hand with an academic focus on institutions and institutional actors, such as courts, international organisations and international NGOs, among others. However, recent works have highlighted the importance of understanding the context of political contestation in which transitional justice processes occur and how transitional justice is developed by grassroot actors from below (García-Godos, 2013, 14; McEvoy and McGregor, 2008).

The approach to international law from below covers different works in international law that focus on the "resistant" or "mobilising" character to the actions of community,

\footnotetext{
${ }^{10}$ See Arts. 13, 34 and 41 of the European Convention of Human Rights; Arts. 25, 44 and 63 American Convention on Human Rights; and Art. 7 of the African Charter on Human and Peoples' Rights and Arts. 5 (3) and 27 Protocol to African Charter. Also, Art. 2 (3), International Covenant on Civil and Political Rights. Some specific human rights conventions also include the right to reparation.

${ }^{11}$ For instance, in a study about victims of mass atrocities in Peru, Mijke de Waardt $(2016,450)$ has argued that, once victims begin to mobilize to fight for their rights, they are 'perceived as projecting a strength that suggests they have overcome their victimization and therefore no longer merit special consideration.'
} 
civil society and other non-state actors in their opposition to powerful hegemonic political, social or economic forces.' (McEvoy and McGregor, 2008, 3). The approach from below assumes a critical view of the traditional actor-based perspective which focuses exclusively on institutional actors and thus neglects the study of noninstitutional ones - such as social movements - and the ways these utilise the language of international law. This way, an approach to international law from below requires taking seriously the usage that non-institutional actors make of international law and the possibility that these uses can influence the way international law may be understood (hence, from below). One such actor is precisely grassroot victim organisations, which can be instrumental in framing certain questions in the language of transitional justice (Tarrow, 2011, 252). In this sense, victims' organisations can be seen not only as recipients of transitional justice measures, but more importantly as political actors (García-Godos, 2013, 254).

When thinking about how grassroot organisations can make use of international law concepts and particularly human rights norms, an important factor is how human rights norms are formulated in universal, abstract terms to reflect 'different, and at times conflicting, purposes - interests and values - of the drafters, as well as the reciprocal assumptions that the drafter had about the world ( ...)' (Petman, 2012, 147). This indeterminate character of human rights means that 'there is nothing in the right itself that would decide them: the right receives meaning only when it is viewed by reference to some context or purpose.' (Koskenniemi, 2009, 143). ${ }^{12}$ This characteristic makes them especially susceptible to being appropriated for different purposes.

In analysing an organisation such as Movice in its use of a legal category, I resort to a number of concepts developed by sociologists of social movements that can be useful to explain the choice of moments and actions analysed here as well as to understand them. First, I focus mainly on actions taken by Movice that are not done by institutional means and, instead, can be understood as contentious actions. According to Tarrow, 2011, 7),

\section{'collective action becomes contentious when it is used by people who lack regular access to representative institutions, who act in the name of new or unaccepted claims, and who behave in ways that fundamentally challenge others or authorities.'}

This concept was particularly fruitful as Movice's work, and the contentious character of its actions, can only be understood if the context of their actions is analysed. ${ }^{13}$ For this reason, when analysing its work, I take considerable space to explain the context of the group's actions so as to uncover their meaning and impact. Moreover, the fact that, in these contentious actions, Movice resorts to the language of international law and the category of the victim of mass atrocities helps them to create meanings and frame their demands. In this sense, the language of international law is a way for Movice to inscribe their grievances

\footnotetext{
${ }^{12}$ As Petman $(2012,126)$ has thoroughly explained, indeterminacy does not necessarily lead to arbitrariness, instead there are patterns in decision making that can be explained by institutional culture. 'The claim of indetereminacy is quite simply that none of these patterns and regularities are necessary consequences of rules.' On the idea of indeterminacy in international law see: Koskenniemi, 2009.

${ }^{13}$ Other works have instead focus on more institutional actions of Movice. See: Sandoval Rojas, 2015; Gómez Sánchez, 2014.
} 
as universal, identify themselves as victims and thus attribute responsibility to others, activities that are central for social movements (Tarrow, 2011, 145-6).

The concept of political opportunities was also used loosely to identify and evaluate the different episodes analysed in this article. The political opportunity is the perceived (and not objective) probability that an action - in this case a contentious one - will lead to success (Goldstone and Tilly, 2001, 182). The opportunity is comprised by different dimensions of the political environment that provide incentives for collective action and thus influence the expectations of success or failure (Gamson and Meyer, cited in Tarrow, 2011, 163). The most important factors affecting these expectations would be the (i) increased access to participation for new actors, (ii) the instability of political alignments, (iii) the availability of influential allies and (iv) the emerging divisions among elites (Tarrow, 2011, 164 et seq). As I will explain further in the next section, all these factors were present to different extents during the episodes analysed here.

Finally, it is important to clarify that Movice is not the only organisation gathering victims of mass atrocities in Colombia. Moreover, it impossible to isolate the actions of Movice not only from the actions of other organisations, but also from the influence of international human rights networks, and the cumulative effect of the use of human rights language in Colombia, which can be traced back to the 1980s (Tate, 2007, 72 et seq). As sociologists of social movements have highlighted, the difficulty to identify particular movements' actions as the cause of specific outcomes makes it challenging to establish a causal relation between social movements and their outcomes. In addition, social movements are not the only ones who respond to political opportunities, elites and authorities also do, but in different ways (Tarrow, 2011, 216).

\section{Movice and the Category of Victim From Below}

\section{The Movement of Victims of State Crimes: Movice}

Movice was created on 25 June 2005, during the II National Encounter of Victims of Crimes Against Humanity (Movice, 2015a). As an umbrella organisation, it convenes both individual victims as well as victims' and human rights organisations throughout the country. Movice's internal organisation includes a national-level structure as well as several regional chapters. Even though human rights and victims' organisations have had a long history in Colombia, the victims' organisations used to act separately as they gathered around specific types of crime (Gómez Sánchez, 2014, 136). Movice became the first space that brought together different human rights and victims' organisations under the same name. ${ }^{14}$ Its members include direct and indirect victims of forced displacement, extrajudicial executions and forced disappearance, among others.

Even though, as I will show later in this article, the discussions of the Justice and Peace Law triggered the creation of Movice, this organisation has roots in an earlier project: Colombia Nunca Más (CNM) (Movice, 2010a, 4-5). Initiated in 1995, CNM aimed at gathering and systematising information about human rights violations in Colombia (Colombia Nunca Más, 2008a). Unlike other 'Nunca Más' projects in the region, CNM was created in the context of a democracy with no transitional justice measures applied.

${ }^{14}$ In 2007, two other spaces to organize victims' mobilization were created (Gómez Sánchez, 2014, 132-5). 
Thus, a main objective is to uncover repeated patterns and contexts of victimisation in order to fight against impunity (Colombia Nunca Más, 2008b) and to make visible that the Colombian state was also a-direct and indirect - perpetrator of crimes against social movements and political opposition. As a continuator of CNM's work, Movice aims at highlighting how the state has used violence against the political opposition.

Although its name suggests that members are victims only of state crimes, for Movice, violence directly perpetrated by the state is treated as equal to the violence perpetrated by paramilitary groups. ${ }^{15}$ In other words, when Movice speaks about state violence, it is talking about those crimes perpetrated directly by state forces, such as its police, its military forces and intelligence agencies, as well as those crimes perpetrated by paramilitary groups. The reason for this is the perceived closed ties between these two. Equating these two kinds of violence may be perceived as an over-generalisation, especially considering that paramilitary groups were not organised hierarchically and function as semi-autonomous cells (Saffon, Uprimny, 2007, 5). In this sense, it would perhaps be more realistic to think that paramilitary actions respond to different logics, some of which may be completely autonomous, some of them may benefit the government, and in others, the government may be directly involved. However, equating the actions of these two groups allows Movice to use the framework of human rights more effectively as a framework created with a state perpetrator in mind. This does not mean that illegal armed groups' violence cannot be discussed or condemned under the human rights framework ${ }^{16}$; instead, the purpose is asserting that the state is directly complicit in the perpetration of paramilitary crimes.

Furthermore, because Movice gathers victims of state and paramilitary crimes, and not guerrilla crimes, most of the victims sympathise with left-wing ideas or actively participate in leftist organisations or parties. This was apparent in all my interviews. Moreover, one of my interviewees explained this to me: Most of Movice's victims were either politically active themselves before the violation committed against them or their family members or their family members - affected directly by a violation - were politically active before they died or disappeared. ${ }^{17}$ This factor, in a way, contributes to the stigmatisation of their members, who are often under threat and continue to suffer political persecution (Movice, 2010a; Movice, 2010b; Palomino, 2018; El Espectador, 2018).

\section{The Category of Victim From Below: Three Political Opportunities and Movice}

\section{The 'Justice and Peace Law' and the Emergence of Transitional Justice}

The figure of 'the victim' of mass atrocities, as a part of the discourse of transitional justice, only emerged as a relevant actor in the Colombian political context with

\footnotetext{
${ }^{15}$ Diana Gomez Correal, Interview with author, 2018

${ }^{16}$ In fact, the Colombian state has been found responsible for the actions of paramilitary groups by the InterAmerican Court of Human Rights, see for instance IACtHR, Case 19 Merchants v. Colombia. Preliminary Objection. Judgement of June 12, 2002. Series C No. 93; Case of the Pueblo Bello Massacre v. Colombia. Merits, Reparations and Costs. Judgement of January 31, 2006. Series C No. 140; Case of the Ituango Massacres v. Colombia. Preliminary Objection, Merits, Reparations and Costs. Judgement of July 1, 2006. Series C No. 148; Case of the Rochela Massacre v. Colombia. Merits, Reparations and Costs. Judgement of May 11, 2007. Series C No. 163.

${ }^{17}$ Lucia Osorno Ospina, Interview with author, 2018
} 
paramilitary groups' demobilisation process initiated in $2002 .{ }^{18}$ What is more, as highlighted by Saffon and Uprimny (2007), virtually all actors in this discussion ended up adopting the language of transitional justice, though with different meanings and emphasis. In 2003, a first draft legislation to provide a framework for this demobilisation was known as 'Penal Alternativity Project' (Proyecto de Alternatividad Penal). This project did not embrace the language of transitional justice but merely the idea of restorative justice by including mild penal sanctions (excluding prison) for demobilised combatants. Because of this, the project faced resistance as it was seen as almost a blanket amnesty for paramilitaries and was eventually withdrawn. ${ }^{19}$

In the beginning of 2005, new draft bills were submitted to the congress to replace this failed project which would eventually lead to the approval of the Justice and Peace Law. In its process of discussion, the role of international and national NGOs was crucial as they pushed for the inclusion of international standards coming from the discourse of transitional justice, including provisions for victims (Fundación Social, 2006, 78; Gómez Sánchez, 2014, 109; Diaz, 2008). The final text of this law would include general provisions for victims as well as special sections on the rights of victims and reparations. This was a departure from previous peace negotiations that had followed the logic of amnesties with the interests of victims being absent from the discussions. But its definition of victim excluded victims of state crimes.

As Ivan Cepeda, one of the founders of Movice has stated, the passing of the Justice and Peace Law put pressure on a movement of victims that had no clear organisation until then (Vidales Bohoroquez, 2015). Groups of victims had gathered a few times in large events (Encuentro, 2004), and during the discussion of the Justice and Peace Law, different victim activists would find notoriety, such as Cepeda, who interrupted a speech by paramilitary commanders before the congress by showing a picture of a family member killed by paramilitary groups (Gómez, Restrepo, 2004; Abad Faciolince, 2004). But the Justice and Peace Law, with its definition of victims that excluded victims of state crimes, was the final strike that turned this embryonic movement of victims into a nationwide organisation. Three days after the law was passed, Movice was created. In addition, one of Movice's first notorious actions was to challenge, along with other organisations, the content of the Justice and Peace Law before the Constitutional Court (Diaz, 2008, 204 et seq; Gómez Sánchez, 2014, 117 et seq; Sandoval Rojas, 2015). While these challenges achieved some changes that increased the requirements needed to access the penal benefits established in the law, the definition of victimhood remained intact.

At this juncture, the attention of international NGOs represented the availability of influential allies for victims of mass atrocities. Moreover, including the figure of the victim for the first time in such discussions would warrant this emerging actor with

\footnotetext{
18 Thus, 2005, has been indicated as the moment when the framework of transitional justice began to be incorporated in Colombia (Acebedo Pérez, 2016, 219; Gómez Sánchez, 2014, 93). Coincidently, in 2005, two instruments framing victim-oriented measures were adopted at the United Nations, see Basic Principles and Guidelines on the Right to a Remedy and Reparation for Victims of Gross Violations of International Human Rights Law and Serious Violations of International Humanitarian Law, A/RES/60/147; and Updated Set of principles for the protection and promotion of human rights through action to combat impunity E/CN.4/2005/ 102/Add. 1

19 The participation of victims' organizations was not as significant in this moment (Fundación Social, 2006, 36 and 47-9).
} 
increased access to participation. Despite the fact that victims of state crimes were not included in the definition of the victim, this increased access would already grant them the political opportunity to initiate a movement that would soon turn into an organisation: Movice.

What I would like to highlight here is that the choice of the name ('victims of state crimes'), and the creation of a national movement to articulate victims' mobilisation, was a contentious action in direct response to the exclusion of the Justice and Peace Law and what the movement saw as a 'false' demobilisation process (Ivan Cepeda in Vidales Bohoroquez, 2015). Thus, in transforming an embryonic movement into a structured nationwide organisation that gathered victims of state and paramilitary crimes, and in giving it a name that would highlight the role of the first, Movice was directly challenging the basic premise of the peace negotiations between the state and the paramilitary groups. According to this - a central premise to any peace negotiation - the parties involved are former enemies. Instead, Movice is suggesting that the state had a protagonist role - of co-perpetrator or direct perpetrator - in the violence that had been solely attributed to the paramilitaries.

In this context, the wide acceptance of the language of transitional justice by different groups participating in the discussion of the Justice and Peace Law provided legitimacy to a movement that identified itself with a core category of transitional justice: the victims. In referring to themselves as victims, the movement made explicit references to the categories of international law that are directly connected with the victims, for instance, explicitly mentioning the different crimes that had been committed against them, using the categories of international criminal law (Movice, 2005). Moreover, in its Constitution Statement (Acta de Constitución), they state that the movement is created 'as an expression to affirm the right to authentic truth, justice and full reparations' (Movice, 2005). All these references provide legitimacy to a group that had historically suffered political persecution.

Thus, the movement did not simply adopt the category of victim as part of the language of transitional justice, they added specific content to it. In doing so, they had a specific purpose, that is, to highlight the existence of these victims and, as a consequence, to underscore the existence of state violence. An example of this is its Constitution Statement, in which they say this explicitly: '[The Movement] highlights the responsibility of the Colombian state and of those who fund, support, benefit from, and promote the serious irreparable harms the war has generated for millions of Colombians' (Movice, 2005). In a political context in which this responsibility was not acknowledged, this entailed proposing a specific narrative of the conflict. Moreover, the Constitution Statement also mentions that they are formed not only by victims of war crimes, but also by victims of crimes against humanity including political persecution (Movice, 2005). This again entails introducing a narrative about human rights violations committed by both the state and the paramilitaries, which are usually recognised as part of an internal armed conflict. ${ }^{20}$ Instead, what Movice attempts to reveal is that these respond to a different logic, a logic of political violence. Finally, Movice (2005) still adds another idea that goes deeper into what they propose as the 'real causes of the war' which are connected with the 'economic interests of national

\footnotetext{
${ }^{20}$ Here, I refer to a social recognition, because at that moment, the official discourse of the government would deny the existence of an armed conflict.
} 
and transnational capitals' to undertake 'inequitable commercial agreements', 'agroindustrial projects' and 'interests protected and conquered, in many cases, through paramilitary strategies'. Thus, Movice's project goes even deeper in that it suggests that the causes of the internal conflict are related to deep social inequalities, in which the government participates through its own army and through illegal paramilitary violence.

In its creation, Movice turned a social movement into an organisation with a nationwide structure that resorts to the language of international law to frame their demands. By giving the movement a name that would highlight the role of the state as a perpetrator, and the connections between paramilitary and state, the organisation materialised a challenge to the accepted narrative of the conflict. This would enable them to successfully organise a rally against paramilitary violence in 2008 , a moment I analyse in the next section.

\section{The ‘No Más Farc' Rally}

In 2007, a corruption scandal, known as 'para-politica' revealed that several congress members had been receiving money from paramilitary groups (Murillo Delgadillo, 2008). That same year, a draft legislation, known as the 'Victims' Statute', was submitted to the congress. This would, once more, initiate a series of discussions around the victims of mass atrocities, including a number of public hearings that would mobilise thousands of victims across the country for the next 2 years. ${ }^{21}$ In the middle of these discussions, in February 2008, a massive mobilisation entitled 'No Más Farc' ('No More Farc') gathered millions of persons in more than 190 cities around the world (El Espectador, 2008a; Semana, 2008b). The march was held with the support of the government and had a massive attendance that brought attention throughout the globe (Markey, 2008; Forero and Brulliard, 2008; BBC News, 2008).

This was an important political opportunity for Movice. In this conjuncture, two important dimensions shifted which gave rise to this political opportunity. On the one hand, the para-politica scandal entailed both the instability of certain (illegal) political alignments and the division of the elites represented by congress representatives and paramilitary groups. On the other, the Victims' Statute discussion once again represented an opportunity for increased participation by victims of mass atrocities, who had the chance to appear at the public hearings. Furthermore, the 'No Más Farc' demonstration highlighted a specific official narrative of the conflict, according to which the only crimes being acknowledged and rejected were the ones committed by the guerrillas. Indeed, a strong condemnation against crimes committed by the state and the paramilitary groups (now officially demobilised) was not only absent from this rally, but more importantly, it continued to be absent from the official narrative of the conflict. $^{22}$ The fact that this rally - a contentious action itself - counted with so much public support also opened up the possibility of receiving support for a strong condemnation against state and paramilitary violence.

\footnotetext{
${ }^{21}$ Eventually, however, the Victims' Statute was not approved mainly because of the pressures of the government, which argued lack of funds to implement the law (Fundación Social, 2010, 52; Eusse Guerra, 2009).

22 In fact, an opinion poll conducted in 2007 showed that, despite the 'para-politica' corruption scandal, there was a significant group that supported the AUC as a defence mechanism against the guerrilla (Semana, 2007).
} 
Thus, 2 days after the rally, Movice convened a public demonstration against paramilitarism to be held a month later, on 6 March. In a communiqué, Movice asked if those who marched in the mobilisation against Farc would also accompany victims of paramilitary groups, para-politicians (i.e. those who were found to have ties with paramilitary groups) and state agents (El Espectador, 2008b). This was done by resorting to the category of victim as Cepeda stated 'It is not possible that in Colombia thousands of victims appear in pits, that many others have disappeared and that their families go unnoticed (...) victims cannot continue without a public acknowledgement'. He suggested that there was 'a social debt towards the victims' of paramilitary crimes and that the lack of condemnation of these crimes, coupled with the public condemnation of guerrilla crimes, amounted to 'an ethical problem' (Semana, 2008a).

The call was not only unprecedented, but it also contested the official narrative of the Colombian government, which had supported the rally against Farc but did not support Movice's call. On the contrary, by that time, the political environment of Uribe's presidency tended to stigmatise this kind of political mobilisation as aligned with the interests of the public enemy: the guerrillas. For instance, in 2008, Uribe said

There are people in Colombia, like Dr. Iván Cepeda, who hide behind and thrive on the protection of victims to lead NGOs in order to ask funds from the international community. They use the protection of victims to instigate human rights violations against the people that do not share their ideas. And nothing happens to them. They make use of the protection of victims to travel abroad and discredit the Colombian Government and institutions. (OMCT and FIDH, 2009, 179).

Despite the climate of stigmatisation, the march was unexpectedly successful, managing to convene nearly a million demonstrators in different cities inside and outside of Colombia (Semana, 2008a; Semana, 2008c; Gómez Sánchez, 2014, 137). ${ }^{23}$ On the one hand, convening to another march against paramilitary violence implied calling those who participated in the march against guerrilla to acknowledge the existence of other kinds of violence. A massive response to that call, on the other hand, entailed that the assertion of paramilitary and state violence, although it was not necessarily acknowledged by the official discourse of the government, found supporters in the Colombian population while generating attention from the media.

For Movice members, this was a turning point in which the movement gained visibility and support from common people like never before (Movice, 2018; Vidales Bohoroquez, 2015). ${ }^{24}$ Indeed, it has been contended that the March 6 rally introduced a different element to the competing memories of the conflict (García Arboleda, 2013). In this sense, the rally connected the idea of victims' rights with an opposition towards the state as a human rights violator, a connection that was absent from the narrative in which guerrillas and drug trafficking appeared as the sole responsible parties for human rights violations, with paramilitaries considered to be a 'necessary evil' (García Arboleda, 2013, 145 et seq). A proposition that had once been marginal gained traction

\footnotetext{
${ }^{23}$ In the subsequent years, March 6 became a symbolic date despite the fact that the attendance was never again as high as in the first rally.

${ }^{24}$ Diana Gomez Correal, Interview with author, 2018; Luz Marina Hache, Interview with author, 2018
} 
in this conjuncture and received support by the society at large. This does not meant that all of Colombian society accepted this premise, but it meant that a significant number supported the idea that paramilitary structures were also targeting civilian population. Leading members of Movice, such as Ivan Cepeda, also gained visibility in this moment. Two years later, he was elected to the congress.

With such visibility gained in this moment, the movement managed to position itself as an important political actor in the Colombian discussions regarding the conflict and its victims. This would allow them to continue to influence and push for the inclusion of international standards in different discussions. This political traction was also relevant during the discussions leading to the Final Agreement between the government and the FARC-EP, in which Movice continued to push its agenda in different instances. I analyse this moment below.

\section{Habana Negotiations: Which Victims?}

A turning point in the policies regarding the conflict and the consideration of victims was the election of president Santos in 2010. Though Santos had been Minister of Defence during Uribe's presidency, his administration differed from Uribe's in numerous ways. Crucially, unlike his predecessor, his government no longer considered guerrillas as terrorist groups that needed to be confronted militarily. Furthermore, Santos embraced the discourse of transitional justice with its notion of victim more decidedly than before. An example of this is that less than 2 months after taking office, he personally submitted the draft legislation of the Victims' Law to the congress (El País Bogotá, 2010; Santos, 2011). In 2011, the so-called Victims' Law was approved, finally including victims of state crimes within its definition of victims.

Moreover, this shift in attitude towards the conflict and its victims would also give way for the possibility of a negotiated end to the conflict. Thus, when a new peace deal with the Farc officially began to be discussed in 2012, the negotiations were organised in an agenda of six items, the fifth being 'Victims.' Never before had victims been part of the agenda in a peace negotiation process. But this time, the general agreement signed between the government and the Farc to officially initiate the negotiations, explicitly stated: 'redressing victims is at the centre of the National Government FARC-EP Agreement' (Gobierno Nacional y FARC-EP, 2012, 3).

The inclusion of an item focused exclusively on the victims and victims' rights entailed once more - despite all the problems around victims' participation that will be discussed below-increased access for victims and victims' groups, such as Movice. Moreover, the whole process of discussion with the FARC-EP was fragile, and the political alignments that allowed it were unstable. For instance, in 2015, the discussions were seriously jeopardised by the lifting of the FARC-EP's unilateral ceasefire after a bombing by the army that killed 26 FARC-EP combatants (Semana, 2015).

Victims' groups, including Movice, supported the idea of a negotiated solution to the internal conflict (El Espectador, 2014; Movice, 2015b), but they still remained critical of several aspects of the negotiations. This support should be understood in light of Movice's narrative of the conflict: If the guerrillas are no longer considered as mere terrorists and negotiations are possible, their political motivations should also be acknowledged. Consequently, there is a chance to acknowledge the social inequalities that gave way to the creation of the guerrillas in the first place. Indeed, considering 
guerrillas as terrorists - as was done in Uribe's administration - seemingly concealed the complex process of their formation, including the social and political roots of the conflict (Vargas Velásquez, 2012, 197). These social and political roots that highlight profound inequalities are precisely what a number of Movice members I interviewed acknowledge as their own (Lucía Osorno Ospina, Interview, 2018; Luz Marina Hache Contreras, Interview, 2018).

The peace negotiations with the guerrilla also posed an important challenge to Movice as a victims' group that, in gathering only victims of state and paramilitary crimes, attempted to differentiate from guerrilla victims. This difference is a crucial way to highlight the context of their victimisation and the responsibility of the state. Because of this, Movice is reluctant to merge with other victims' groups and particularly, with victims of the guerrilla. This does not mean that they do not collaborate with them. However, if they merged with victims of guerrilla, they would lose their angle to highlight the context of their victimisation, as well as the motivations of the perpetrators which, in their view, are radically different. In this context, Movice questioned the very concept of 'victims of the conflict' and argued that it was a generic category that distorted the nature of the violence to which these people were subjected. But, in resisting this generic category of victim, Movice's demands were, once more, not only about asserting their identity as victims. In addition, they were calling attention to the causes of the conflict. In a communiqué issued in 2015, Movice demanded to clearly differentiate between infractions of international humanitarian law in the context of an armed conflict and those breaches to international human rights law perpetrated as part of political, economic and social conflicts. They highlighted that these conflicts were pre-existing the birth of armed guerrillas, while these had served to justify both the legal strategies and covert operations through paramilitarism aimed at exterminating political and social alternative processes (Movice, 2015b).

Moreover, despite the fact that the victims were one of the items in the peace negotiations, the victims' identity was, perhaps now more than ever before, a contested territory. During this period, according to Gómez Correal (2017), both the state and the guerrilla denied the victims they produced with their actions and tried to establish themselves as victims. Furthermore, as Sáenz Cabezas (2017) shows, throughout the negotiations victims were increasingly invoked by other actors to either support the negotiations or to reject them. But, according to this author, regardless of the fact that victims were being talked about at early stages of the negotiations, direct interventions by actual victims were not done until 2014, that is, almost 2 years after the negotiations were initiated. Indeed, as the universe of victims became larger and larger, reaching around $15 \%$ of the total Colombian population in 2018, they became a legitimating token, and their inclusion in different instances of participation allowed the negotiators to respond to criticisms arguing that the negotiations neglected the interests of victims (Sáenz Cabezas, 2017, 139 et seq).

By 2015, it seemed clear that both critics and supporters of the peace negotiations were using the idea of 'defending the rights of victims' to support their agendas (Bermúdez Liévano, Briceño Florez, 2015). In this landscape, victims themselves, in the words of Gómez Correal (2017), fought for the right to really be central in the discussions leading to the Final Agreement. This entailed an active participation through the channels opened for this objective as well as outside of them. An official participation scheme was implemented, in which, 5 delegations of 12 victims each 
would go to Habana to directly address the table. ${ }^{25}$ A core question emerged here: Which victims should participate? Should only victims of Farc participate or should victims of other armed actors, such as the state or the paramilitaries, be included? In responding to these questions, different competing narratives of the conflict emerged. ${ }^{26}$ The majority of the society, in the words of Gómez Correal (2017), understood that Farc victims should go to Habana and saw no reason for state victims to show up (despite the fact that the state was one of the parties negotiating). This demonstrates that even though there was agreement that the victims were to be central in the negotiations leading to the peace agreement, the majority of the parties involved still saw that the victims were mainly victims of the guerrilla, thus making victims of state crimes invisible (Gómez Correal, 2017). Eventually, the commissions were comprised by a majority of Farc victims (around half of them), with victims of other armed actors also being represented (Sáenz Cabezas, 2017, 142). ${ }^{27}$

Nevertheless, this climate of widely accepting the importance of victims' rights even though the identity of the victim was contested-was another opportunity for Movice to assert the Colombian state's responsibility, especially considering that the state was represented at the negotiating table. Already in 2013, Movice officially issued a 64-page publication, which would be sent, through a UN representative, to the negotiating table (El Colombiano, 2013; El Espectador, 2013). This document entitled 'Minimum Proposals about Truth, Justice, Reparations and Guarantees of Non-Repetition' contained a series of specific proposals for the negotiating table, such as the creation of a truth commission, the establishment of collective reparations with regard to political persecution against members of political opposition, among others (Movice et al., 2013, 25-9 and 37-8). Movice's requests and demands for acknowledgment of victims of state crimes continued throughout the negotiations; for instance, in 2015, Movice requested that victims of state crimes be acknowledged explicitly (El Colombiano, 2015).

But the purported centrality of victims, even though contested, eventually arrived to a decisive moment. The negotiations were finalised on 26 September 2016 with the parties agreeing to submit the Final Agreement to a referendum in which citizens could vote for ('yes') or against ('no') the agreement. A strong campaign against the agreement was led by former president Uribe, which ultimately won the plebiscite. The triumph of 'no' left its leaders in a strong position to negotiate changes in the Final Agreement. Within this context, Movice became one of the leading organisations within a platform of organisations supporting the 'yes' alternative. However, the attitude of the government had changed from before to after the triumph of the 'no' going from an attitude of willingness to discuss with groups as Movice to sidelining them while giving more attention to the negotiations with the 'no' representatives (Gómez Correal, Interview, 2018). In an open letter, Movice requested that President

\footnotetext{
${ }^{25}$ The Congress organized two regional working rounds for victims of the conflict to discuss and submit their proposals to the negotiating table, the negotiation table also organized forums around the country with regard to the topics that were being discussed (Sáenz Cabezas, 2017, 131-132).

${ }^{26}$ For instance, Farc victims, as well as some politicians, would defend the idea that only Farc victims should participate as they saw that victims of state crimes had little criticism over Farc's actions, even suggesting that they would be selected and instructed by Farc supporters (Sáenz Cabezas, 2017, 146).

${ }^{27}$ Some victims belonging to Movice took part on these delegations, although these did not go as Movice representatives, but as individuals, a situation that was criticized by members of the movement.
} 
Santos would not modify the Final Agreement as, they argued, the proposals of the supporters of 'no' would only benefit state agents and other third parties responsible for human rights violations (El Espectador, 2016). Eventually, a modified Final Agreement, discussed and negotiated without the presence of the Movice, was finally signed in November 2016 and entered into force on December 1 that same year.

The triumph of the 'no' option came as a surprise, not only for Movice members, but also for the government. ${ }^{28}$ Although some of the victims I interviewed saw the signature of the agreement with scepticism and doubted that it would in fact mean the end of political persecution, ${ }^{29}$ they still described the deep symbolic significance it had for them that the agreement assigned such a central place to the victims. ${ }^{30}$ For this reason, the triumph of 'no' was described by some members as a pivotal moment ${ }^{31}$ that changed the dynamic of discussions. Indeed, the government had to hold new negotiations with the representatives of the 'no,' in order to save the Final Agreement. Victims' interests, which had had a relative central place in the peace agreement discussions, were not central anymore in these re-negotiations. Instead, the negotiations with the representatives of the 'no' put at the forefront the interests of a sector that had been against the peace process all along. As a consequence, victims were reduced to a marginal position in the view of Movice (Colombia Plural, 2017). ${ }^{32}$

Even though Gomez Correal explains the marginalisation of the victim in terms of concrete provisions that were either modified or excluded from the Final Agreement or in the so-called Fast Track, ${ }^{33}$ it is my impression that the marginalisation she describes is a more political one. The boost that the discourse of the victim found in these discussions, and the actions of Movice in resorting to it, faced an important limit when others began to use the image of the victim to their advantage. Indeed, although victims had had an important role in the earlier discussions of the Final Agreement, with the triumph 'no,' they were not allowed to take part in the negotiations of the Modified

\footnotetext{
${ }^{28}$ The words of President Santos in his Nobel lecture illustrate this: 'We felt that we ourselves were inhabitants of Macondo, a place that was not only magical but also contradictory.' (Santos, 2016).

${ }^{29}$ Erik Arellana, Interview with author, 2018; Blanca Nubia Diaz, Interview with author, 2018; Diana Gomez Correal, Interview with author, 2018

${ }^{30}$ Lucia Osorno, Interview with author, 2018; Diana Gomez Correal, Interview with author, 2018

${ }^{31}$ Diana Gomez Correal, Interview with author, 2018; Blanca Nubia Diaz, Interview with author, 2018

${ }^{32}$ Diana Gomez Correal, Interview with author, 2018

${ }^{33}$ Gomez Correal explained to me that there were important aspects that changed in the modified final agreement. First, the final agreement included the possibility of prosecuting the most responsible ones by applying the doctrine of command responsibility; this was excluded from the modified final agreement. Second, during the discussions of the so-called Fast Track, the responsibility of third persons was excluded from the jurisdiction of the special courts created for that purpose. This would leave institutions such as DAS (the Administrative Department for Security) outside of the jurisdiction of these courts (Diana Gomez Correal, Interview, 2018). When checking these questions, I found that with respect to the first point, the modified agreement actually specifies the interpretation of one of the elements of the doctrine of command responsibility, namely the requirement of 'effective control', making it more specific and linking it to article 28 of the Rome Statute (see: Modified Final Agreement, p. 151-2, para. 44.). With respect to the second point, the 'Legislative Act' (Acto Legislativo) 1 (4 April 2017) excluded the possibility of third parties to be included in the special jurisdiction for peace but only for crimes related with money laundering. With respect to state agents, their crimes can be considered for the special jurisdiction for peace (see: Articles 16 and 17). See also: Gomez Correal, 2017, p. 5. The Fast Track is an accelerated special procedure aimed at achieving a fast approval of constitutional and legislative reforms needed to implement the Final Agreement. This procedures was both praised and criticized; on the one hand, it allowed for a prompt commencement of the procedures against former FARC-EP members; on the other, it did not allowed the congress to influence on the content of these reforms which needed to be accepted as they came from the government. See: Semana, 2016.
} 
Final Agreement or in the final process of the definition and presentation of the mechanisms regarding victims in the Fast Track (Gómez Correal, 2017). Thus, an actor that had been strongly campaigning for the Final Agreement was no longer granted a space to participate in the process.

\section{Conclusions}

In this article, I have sought to explore the use of the category of victim from international law by a grassroot movement of victims. In this, I have found that the movement does not simply invoke the legal category without adding any specificities, but it infuses it with specific contents. These contents can only be fully understood if the context of the political opportunities in which the category emerges is considered. To conclude, I would like to reflect on the effects that the work of Movice has had in resorting to international law categories, its challenges and the possibilities of the language of international law for emancipation.

In its actions, Movice has been successful in achieving - together with many other initiatives - certain institutional changes that recognise victims' rights and acknowledge victims of state crimes, such as the Victims' Law or the peace agreement signed between the Farc and the Colombian government. ${ }^{34}$ This way, I suggest that they have successfully contributed 'to collective goods that benefit those they claim to represent' (Tarrow, 2011, 231 et seq), that is, victims of mass atrocities. However, the alternative narrative to the conflict they propose - in which violence suffered by victims of state crimes cannot be explained fully by the existence of an internal armed conflict, but by a sustained practice of political persecution - has not yet been accepted by the Colombian establishment.

Thus, perhaps the biggest success of the movement has to do with a cultural change (Tarrow, 2011, 231 et seq). Today, in Colombia, it is acknowledged that victims in the context of the internal conflict have been produced not only by the guerrillas, but also by the state and the paramilitary (e.g. GMH, 2013, 35). Movice has become a relevant actor in discussions regarding victims in Colombia. Moreover, as I have discussed at length elsewhere (Tapia Navarro, 2017) victims of mass atrocities are often represented in international law as defenceless, passive, docile and in need for external support. Movice's actions contradict this image in showing how a group of victims of mass atrocities is able to position itself as a relevant actor in the discussions regarding the internal armed conflict in Colombia by using a vocabulary developed by instruments of international law. Thus, Movice's actions in over 10 years allow us to understand how the use of a legal category can allow its operators to influence its content, to change it and to redraw its contours. This is particularly relevant in a group that has claimed to be subjected to sustained political persecution and thus had no other means to participate in the political discussion. Nowadays, such impediments have softened as seen, for instance, with the election of Ivan Cepeda as a representative in congress. However, Movice members still face political persecution, especially in the regional chapters.

But the success of the category of victim comes with a price. Sáenz Cabezas (2017, 139 et seq) argues that victims became, at some point during the peace negotiations,

\footnotetext{
${ }^{34}$ See Section 2 on the impossibility to trace the effects of a particular movement.
} 
'phantom actors' that only had visibility when integrated in the discourse of others to justify support or rejection towards the negotiations. It is difficult not to see some similarities between these 'phantom actors' and what - in the context of the International Criminal Court-Fletcher refers to as the 'imagined victim', which is nothing more that the victims of mass atrocity crimes as 'invoked by the protagonists of ICJ as one of the primary moral justifications for this unique enterprise' (2015, 302; similarly, Kendall, Nouwen, 2014; Clarke, 2009, 92). Thus, it seems that the power of victimhood is precisely the power to appeal to important - and seemingly incontestablemoral reasons that can be used to justify a particular enterprise (Fassin, 2012, 1), be it a negotiated agreement with a 50-year-old guerrilla group, or the rejection of it, or the work of an international court to try cases of mass atrocities. But the main issue is that the power of victimhood in appealing to seemingly incontestable moral reasons is also available to actors who claim to be victims themselves or to act on behalf of the victims' better interest.

Moreover, Movice's use of the category of victim entails an acceptance of the normative dimension of the discourse of transitional justice because they invoke it as having binding power with which the state must comply (Saffón, Uprimny, 2007). In this sense, Saffón and Uprimny suggest that the transitional justice discourse had different uses in the context of the paramilitary demobilisation of 2005. For these authors, there was a 'manipulative' use - reflected in the actions of the government and the paramilitary groups - which entailed adopting it only as a rhetorical instrument, even though no material transformation was done (Saffón, Uprimny, 2007, 15). And there was also a 'democratic or emancipatory' use - reflected in the actions of victims groups and NGOs - which took transitional justice content seriously and interpreted it as having an actual normative or legally binding dimension. For the authors, the democratic use of transitional justice 'consists precisely in claiming the effective application of its mechanisms' (Saffón, Uprimny, 2007, 16).

However, I believe that analysing the case of Movice shows that they also, to a certain extent, manipulate transitional justice discourse to their own ends. Unlike Saffón and Uprimny, I do not mean 'manipulative' in a negative way, but instead, refer to the skill of handling a tool, in this case, a legal category, in a skilful manner. ${ }^{35}$ The way in which victims of state violence in Colombia use the legal category of the victim as a tool is by introducing different elements that may not be explicit in that discourse, such as when talking about victimisation, by focusing on the context of the victimisation in order to denounce a specific logic of violence. This is possible due to the indeterminate character of human rights norms that are often formulated in abstract terms (Petman, 2012).

I contend that thinking about the victims' use of the category of victim as 'manipulative' in the way described above is fully consistent with the idea of a use that is 'democratic or emancipatory'. Moreover, this understanding of the use of legal concepts by victims of mass atrocities sheds light on how their actions are strategic, serving in this case for unveiling a form of violence that is not widely recognised. Thus, international law categories, such as victim, can have emancipating effects precisely in that victims appropriate them and use them as tools to frame their demands of justice. In this sense, establishing a dichotomy between a 'manipulative' and a 'democratic' use

$\overline{35}$ https://en.oxforddictionaries.com/definition/manipulation 
highlights only the fact that the use of the category can have both positive and negative implications, but obscures the agentic process of appropriation that victims exercise when resorting to international law categories. It is precisely this agentic process that I have sought to show in these pages by representing the work of Movice. Showing this agentic process, moreover, is particularly important in understanding the workings of an actor that is usually portrayed as essentially powerless. Finally, this agentic process relates not only to the choice of a particular repertoire of actions to which the movement resort to provoke disruption, but also to the meanings that they infuse in the different categories they use, among them, legal categories. It is in this agentic process that the use of international law categories can be emancipating.

Acknowledgements I would like to thank René Urueña for guiding me in the four months I spent in Colombia which were crucial to this research. I am also thankful to the members of Movice that helped me during the research for this paper by agreeing to meet and talk with me. Their views and knowledge were essential to my research, but they also taught me to appreciate the immense courage of their struggle, this is a lesson I keep for life. I would also like to thank Guilherme Vasconcelos, Freek Van Der Vet and Jarna Petman, for their words of support and valuable comments to earlier versions of this article and to the anonymous reviewers, whose comments allowed me to improve the quality of this piece.

Funding Information Open access funding provided by University of Helsinki including Helsinki University Central Hospital.

Open Access This article is distributed under the terms of the Creative Commons Attribution 4.0 International License (http://creativecommons.org/licenses/by/4.0/), which permits unrestricted use, distribution, and reproduction in any medium, provided you give appropriate credit to the original author(s) and the source, provide a link to the Creative Commons license, and indicate if changes were made.

\section{References}

Abad Faciolince H (2004) Paras en el Congreso https:/www.semana.com/portada/articulo/parascongreso/67269-3 (last accessed: 3 May 2018).

Acebedo Pérez L (2016)Las Víctimas de crímenes de Estado en Colombia: De la Invisibilidad a la Construcción de una Identidad Dignificada. In: Pardo Abril N, Ruiz Celis J (eds) Víctimas, Memoria y Justicia: Aproximaciones Latinoamericanas al Caso Colombiano. Universidad Nacional de Colombia, Bogotá.

Alcoff, Linda (1991-1992) The Problem of Speaking for Others. Cultural Critique 20:5-32.

BBC News (2008) Colombians in huge Farc protest (4 February) http://news.bbc.co.uk/2 /hi/americas/7225824.stm (last accessed: 4 May 2018)

Bermúdez Liévano A, Briceño Florez E (2015) El Cotice de las Víctimas (9 April) http://lasillavacia.com/ historia/el-cotice-de-las-victimas-49888 (last accessed: 13 June 2018).

Cançado Trindade A (2011) The Access of Individuals to International Justice. Oxford, Oxford University Press.

Clarke K (2009) Fictions of Justice: The International Criminal Court and the Challenge of Legal Pluralism in Sub-Saharan Africa. Cambridge University Press, Cambridge.

Colombia Nunca Más (2008a) Quiénes somos? - El Proyecto y su Despegue' www.movimientodevictimas. org/ nuncamas/index.php?option $=$ com_content $\&$ view $=$ article $\&$ id $=1:$ quienes-somos $\&$ catid $=35$ \&Itemid=582\&showall=\&limitstart=1 (last accessed: 8 March 2018)

Colombia Nunca Más (2008b) Objetivos http://www.movimientodevictimas.org/ nuncamas/index. php?option=com_content\&view=article\&id=2\&Itemid=311 (last accessed: 8 March 2018) 
Colombia Plural (2017) Las Víctimas ya no estamos en el centro del proceso de paz (17 February) https:/colombiaplural.com/las-victimas-ya-no-estamos-centro-del-proceso-paz/ (last accessed: 4 May 2018).

Delgado Barón M (2011) Las Víctimas como Sujetos Políticos en el Proceso de Justicia y Paz en Colombia: Discursos imperantes y disruptivos en torno a la reconciliación, la verdad, la justicia y la reparación. Dissertation, Flacso Mexico.

Diaz C (2008) Challenging Impunity from Below: The Contested Ownership of Transitional Justice in Colombia. In: McEvoy K, McGregor L (eds.) Transitional Justice from Below Grassroots Activism and the Struggle for Change. Hart Publishing, Oxford and Portland.

El Colombiano (2013) Víctimas enviaron propuesta a la mesa de diálogo de La Habana (6 March) http://www. elcolombiano.com/historico/victimas_enviaron_propuesta_a_la_mesa_de_dialogo_en_la_habanaNEEC_232078 (last accessed: 24 April 2018).

El Colombiano (2015) Víctimas de crímenes del Estado piden un reconocimiento particular (20 December) http:/www.elcolombiano.com/colombia/paz-y-derechos-humanos/victimas-de-crimenes-de-estadopiden-un-reconocimiento-particular-NJ3319168 (last accessed: 24 April 2018).

E1 Espectador (2008a) Familiares no quieren odios, sino la vida de los plagiados (6 February) https://www. elespectador.com/noticias/paz/articulo-familiares-no-quieren-odios-sino-vida-de-los-plagiados (last accessed: 30 January 2018).

El Espectador (2008b) Víctimas de 'paras' convocan marcha para 6 de marzo (6 February) https://www. elespectador.com/noticias/paz/articulo-victimas-de-paras-convocan-marcha-6-de-marzo (last accessed: 30 January 2018).

El Espectador (2013) Víctimas reclaman al Gobierno que reconozca los crímenes de Estado (6 March) https:/www.elespectador.com/noticias/paz/victimas-reclaman-al-gobierno-reconozca-los-crimenes-dearticulo-408679 (last accessed: 24 April 2018).

El Espectador (2014) Víctimas de Estado exigen a Gobierno reanudar diálogos de paz con las Farc (18 November) https://www.elespectador.com/noticias/paz/victimas-de-estado-exigen-gobierno-reanudardialogos-de-articulo-528132 (last accessed: 24 April 2018).

El Espectador (2016) Víctimas del Estado piden a Santos no retroceder en lo pactado con las Farc (5 October) https:/www.elespectador.com/noticias/judicial/victimas-del-estado-piden-santos-no-retroceder-pactadoarticulo-658690 (last accessed: 4 May 2018).

El Espectador (2018) Piden medidas cautelares a la CIDH para frenar asesinatos de líderes sociales https://www.elespectador.com/noticias/judicial/piden-medidas-cautelares-la-cidh-para-frenar-asesinatosde-lideres-sociales-articulo-753408 (last accessed: 3 May 2018).

El País Bogotá, C (2010) La ley de víctimas, el primer reto de Juan Manuel Santos (28 September), available at: http://www.elpais.com.co/colombia/la-ley-de-victimas-el-primer-reto-de-juan-manuel-santos.html (last accessed: 10 December 2018).

Encuentro Voces del Mundo por la Vida en Colombia (2004) Final Declaration (26-28 August) available at: https://movimientodevictimas.org/declaracin-final-voces-del-mundo-por-la-vida-en-colombia-primerencuentro-movice/ (last Accessed: 26 November 2018).

Eusse Guerra J (2009) Falta de plata tumbó la ley de víctimas (19 June) http://www.elcolombiano. com/historico/falta_de_plata_tumbo_la_ley_de_victimas-OJEC_48547 (last accessed: 26 November 2018)

Fassin D (2012) Humanitarian Reason. A Moral History of the Present. University of California Press, Berkeley.

Fletcher L (2015) Refracted Justice: The imagined victim and the International Criminal Court. In De Vos C et al (eds.), Contested Justice: The Politics and Practice of International Criminal Court Interventions. Cambridge University Press, Cambridge.

Forero J, Brulliard K (2008) Anti-FARC Rallies Held Worldwide (6 February) http://www.washingtonpost. com/wp-dyn/content/article/2008/02/04/AR2008020403019.html (last accessed: 4 May 2018)

Fuentes-Becerra D, (2016) Atehort8)m/wp-dyn/content/article/2008/02/04/ AR2008020403019.html0403019.html De Vos C et al (ed Opinión Jurídica 29:65-77.

Fundación Social (2006) Trámite de la Ley de Justicia y Paz: Elementos para el control ciudadano al ejercicio del poder politico. Fundación Social, Bogotá.

Fundación Social (2010) La Agenda de las Víctimas en el Congreso 2007-2009. Fundación Social, Bogotá. García Arboleda JP (2013) El Lugar de las Víctimas en Colombia. Temis, Bogotá 
García-Godos J (2013) Victims' Rights and Distributive Justice: In Search of Actors. Human Rights Review $14: 241-255$.

García-Godos J, Andreas Lid K (2010) Transitional Justice and Victims' Rights before the End of a Conflict: The Unusual Case of Colombia. J. Lat. Amer. Stud. 42, 487-516.

GMH (2013) Basta Ya! Colombia: Memorias de guerra y dignidad. Imprenta Nacional, Bogotá.

Gobierno Nacional y FARC-EP (2012) Acuerdo General para la terminación del conflicto y la construcción de una paz estable y duradera. Available at: http://www.altocomisionadoparalapaz.gov.co/procesos-yconversaciones/acuerdo-general/Documentos\%20compartidos/Acuerdo_General_para_la_terminacion_ del_conflicto.pdf (last accessed: 10 December 2018).

Goldstone J, Tilly C (2001) Threat (and Opportunity): Popular Action And State Response In The Dynamics Of Contentious Action. In: Aminzade R, Goldstone J, McAdam D, Perry E, Sewell W, Tarrow S, et al. Silence and Voice in the Study of Contentious Politics. Cambridge University Press, Cambridge.

Gómez Correal D (2015) Of Love, Blood and the Belly: Politicization of Intimate Ties of Caring and Belonging in Colombia. Doctoral Dissertation, University of North Carolina at Chapel Hill.

Gómez Correal D (2016) De Amor, Vientre y Sangre: Politización de lazos íntimos de pertenencia y cuidado en Colombia. En Otras Palabras 23:103-119

Gómez Correal D (2017) Les droits des victims dans les accords de paix de La Havane. IdeAs (Online) 9. URL : http:// ideas.revues.org/1846; https://doi.org/10.4000/ideas.1846

Gómez M, Restrepo O (2004) Paras: 120 Minutos en el Congreso http://www.eltiempo. com/archivo/documento/MAM-1512042 (last accessed: 3 May 2018)

Gómez Sánchez G (2014) Justicia Transicional en Disputa. Universidad de Antioquia, Medellín.

Guzmán DE, Sanchez NC, Uprimny R (2010) Colombia. In: Fundación para el Debido Proceso Legal, Las Víctimas y la Justicia Transicional ¿Están Cumpliendo los Estados Latinoamericanos con los Estándares Internacionales? Fundación para el Debido Proceso Legal, Washington.

IEPRI (2006) Nuestra guerra sin nombre. Transformaciones del conflicto en Colombia. Norma, Bogotá.

Jimeno M et al (2015) Despu sin nombre. Transformaciones del conflicto en Colombia. Universidad Nacional de Colombia, Bogotá.

Kendall S, Nouwen S (2014) Representational Practices at the International Criminal Court: The Gap between Juridified and Abstract Victimhood'. Law \& Contemp. Probs. 76:235-262

Koskenniemi, Martti (2009) The Politics of International Law in Cursos Euromediterráneos Bancaja de Derecho Internacional. Tirant lo Blanch, España.

Madlingozi T (2010) On Transitional Justice Entrepreneurs and the Production of Victims. Journal of Human Rights Practice. 2:208-228.

Markey P (2008) Colombians take to streets in huge anti-FARC march (5 February) https://www.reuters. com/article/us-colombia-hostages/colombians-take-to-streets-in-huge-anti-farc-marchidUSN0459656620080205 (last accessed: 4 May 2018)

Mc EvoyK (2008) Letting Go of Legalism: Developing a 'Thicker' Version of Transitional Justice. In: McEvoy K, McGregor L (eds.) Transitional Justice from Below Grassroots Activism and the Struggle for Change. Hart Publishing, Oxford and Portland.

McEvoy K, McConnachie C (2013) Victims and Transitional Justice: Voice, Agency and Blame. Soc \& Leg Stud 22:489-513.

McEvoy K, McGregor L (2008) Transitional Justice From Below: An Agenda for Research, Policy and Praxis. In: McEvoy K, McGregor L (eds.) Transitional Justice from Below Grassroots Activism and the Struggle for Change. Hart Publishing, Oxford and Portland.

Movice (2005) Acta del Constitución del Movimiento Nacional de Víctimas (25 Junio) available at: https:/movimientodevictimas.org/acta-de-constitucin-del-movimiento-nacional-de-vctimas-segundoencuentro-movice/ (last accessed 26 November 2018).

Movice, (2010a) Las Víctimas del Conflicto Armado en Colombia. Movice, Bogotá.

Movice (2010b) La Revictimización al Movice. Movice, Bogotá.

Movice (2015a) Historia. http://www.movimientodevictimas.org/?q=content/historia (last accessed: 8 March 2018)

Movice (2015b) Víctimas de Crímenes de Estado saludan el Acuerdo sobre Víctimas, exigen reconocimiento como tales y proponen la creación de una subcomisión de garantías de no repetición http://www. movimientodevictimas.org/?q=content/v\%C3\%ADctimas-de-cr\%C3\%ADmenes-de-estado-saludan-elacuerdo-sobre-v\%C3\%ADctimas-exigen-reconocimiento-como (last accessed: 25 April 2018). 
Movice (2018) D: 25 April 2018).org/?q=content/v\%C3\%ADctimas-de-cr\%C3\%ADmen-2018 (Audiovisual resource) https:/www.youtube.com/watch?v=-bkSNX65jfE (last accessed: 15 April 2018)

Movice et al (2013) Propuestas M-bkSNX65jfE=-bkSNX65jfE" mas-de-cr\%C3\%ADmenes-de-estadosaludan-el-acue

Murillo Delgadillo MF (2008) La parapolítica en Colombia: otro elemento del poder público. Derecho y Realidad 11:141-159.

Mutua M (2001) Savages, Victims, and Saviors: The Metaphor of Human Rights Harv. Intblico. Derecho 209.

Norwegian Refugee Council (NRC) (2019) More violence marks beginning of 2019 in Colombia. Available at: https://www.nrc.no/news/2019/january/more-violence-marks-beginning-of-2019-in-colombia/. Accessed 26 June 2019

Palomino S (2018) La campaña de intimidación contra las víctimas de Colombia https:/elpais. com/internacional/2018/01/25/colombia/1516887594_663785.html (last accessed: 3 May 2018)

Pardo Abril N, Ruiz Celis J (eds) (2016) Víctimas, Memoria y Justicia: Aproximaciones Latinoamericanas al Caso Colombiano. Universidad Nacional de Colombia, Bogotá

Pedraza O, Álvarez C (2016) Maquinarias Transicionales y Neutralización Política de las Víctimas en Colombia. In: Pardo Abril N, Ruiz Celis J (eds) Víctimas, Memoria y Justicia: Aproximaciones Latinoamericanas al Caso Colombiano. Universidad Nacional de Colombia, Bogotá.

Petman, Jarna (2012) Human Rights and Violence: The hope and fear of the liberal world. Doctoral Dissertation, University of Helsinki, Finland.

Phillips N, Hardy C (2002) Discourse Analysis. SAGE Publications, Thousand Oaks.

Quintana L (2016) Derechos, desacuerdo y subjetivación política. In: Fjeld A et al (eds.),Movimientos Sociales y Subjetivaciones Políticas.

Rettberg A (2013) Victims of the Colombian Armed Conflict: The Birth of a Political Actor. SSRN https://doi. org/10.2139/ssrn.2317270

Reuters (2019) Violence in some areas of Colombia has worsened since peace deal, Red Cross says. Available at: https://www.reuters.com/article/us-colombia-violence/violence-in-some-areas-of-colombia-hasworsened-since-peace-deal-red-cross-says-idUSKCN1R926I. Accessed 26 June 2019

Sáenz Cabezas M (2017) Las Víctimas como Protagonistas. Exigencias y Disputas por su Reconocimiento In: Guzmán N, et al, La Paz en Primera Plana, medios de comunicación y proceso de paz en Colombia, 2012-2015. Universidad Nacional de Colombia, Bogotá.

Saffon MP and Uprimny R (2007) Uses and Abuses of Transitional Justice in Colombia. Available at: https://www.dejusticia.org/en/uses-and-abuses-of-transitional-justice-in-colombia/. Accessed 26 June 2019)

Sandoval Rojas N (2015) Movilizarse ante la corte: trayectoria y efectos de tres episodios de movilización legal constitucional de feministas, indígenas y víctimas de crimenes de Estado en Colombia. Universidad de los Andes, Bogotá.

Santos JM (2011) Palabras del Presidente de la República, Juan Manuel Santos Calderón, en el acto de sanción de la Ley de Víctimas y de Restitución de Tierras. Avaliable at: http://wsp.presidencia.gov.co/Prensa/2011 /Junio/Paginas/20110610_07.aspx. Accessed 26 June 2019

Santos JM (2016) Nobel Lecture. Peace in Colombia: From the Impossible to the Possible. Available at: https://www.nobelprize.org/nobel_prizes/peace/laureates/2016/santos-lecture_en.html

Schwöbel-Patel, Christine (2016) Spectacle in International Criminal Law: The fundraising image of victimhood. London Review of International Law 4: 247-274.

Semana (2007) La gran encuesta de la parapolítica (5 May) https://www.semana.com/nacion/articulo/la-granencuesta-parapolitica/85319-3 (last accessed: 26 November 2018).

Semana (2008a) Iv26 November 2018).ulo/la-gran-encuesta-parapolitica/85319-3tica/85319-3" image of victimhood. London Revhttp://www.semana.com/on-line/articulo/ivan-cepeda-queremos-rinda-justohomenaje-victimas-del-paramilitarismo/90881-3 (last accessed: 15 April 2018).

Semana (2008b) La Gran Marcha (9 February) http:/www.semana.com/nacion/articulo/la-granmarcha/90930-3 (last accessed: 15 April 2018).

Semana (2008c) Colombia cansada de violencia (6 March) http://www.semana.com/on-line/articulo/colombiacansada-violencia/91432-3 (last accessed: 15 April 2018)

Semana (2015) La Paz Herida (23 May) https://www.semana.com/nacion/articulo/la-paz-herida/428737-3 (last accessed: 3 May 2019) 
Semana (2016) ¿Qué es el 'fast track'? (13 December) https:/www.semana.com/nacion/articulo/fast-track-quees-y-por-que-es-importante/509302 (last accessed: 3 May 2019).

Tarrow S (2011) Power in Movement. Social Movements and Contentious Politics, 3rd ed. Cambridge University Press, Cambridge.

Tapia Navarro, N (2017) Victims of Mass Atrocity: An Emancipatory Reading. Paper presented at 3rd Session of Permanent Seminar CIFDE, Faculty of Law, Universidad de Valparaíso, Chile. On file with the author.

Tate W (2007) Counting the Dead: The Culture and Politics of Human Rights Activism in Colombia. University of California Press, Berkeley.

Urueña R (2012) No Citizens Here: Global Subjects and Participation in International Law. Martinus Nijhoff Publishers, Leiden.

Vargas Velásquez A (2012) Las Fuerzas Armadas en el Conflicto Colombiano: Antecedentes y Perspectivas. La Carreta, Medellín.

Vera Lugo JP (2016) Transitional Justice, Memory, and the Emergence of Legal Subjectivities in Colombia. In: Brunnegger S, Faulk K (eds) A Sense of Justice: Legal Knowledge and Lived Experience in Latin America. Standford, Standford University Press.

Vidales Bohoroquez R (2015) Somos Semilla (Audiovisual documentary, Kinorama) available at: https://www.youtube.com/watch?v=uJa7pIC5JRg . Accessed 16 April 2018

de Waardt, Mijke (2016) Naming and Shaming Victims: The Semantics of Victimhood. International Journal of Transitional Justice 10: 432-450.

Wilson R (2009) Representing Human Rights Violations: Social Contexts and Subjectivities. In Goodale M (ed.) Human Rights: An Anthropological Reader. Wiley-Blackewell, Oxford.

World Organisation against Torture (OMCT) and the International Federation for Human Rights (FIDH) (2009) Steadfast in Protest: The Annual Report. Available at: https:/www.fidh.org/en/issues/humanrights-defenders/archives-human-rights-defenders/annual-reports/Steadfast-in-protest,6686

Publisher's Note Springer Nature remains neutral with regard to jurisdictional claims in published maps and institutional affiliations. 